\title{
White-toothed shrews (Mammalia, Soricomorpha, Crocidura) of coastal islands of Vietnam
}

\author{
Alexei V. Abramov ${ }^{1,4}$, Anna A. Bannikova², Viatcheslav V. Rozhnov ${ }^{3,4}$ \\ I Zoological Institute, Russian Academy of Sciences, Universitetskaya nab. 1, Saint Petersburg 199034, Russia \\ 2 Lomonosov Moscow State University, Vorobievy Gory, Moscow 119992, Russia 3 A.N. Severtsov Institute of \\ Ecology and Evolution, Russian Academy of Sciences, Leninskii pr. 33, Moscow 119071, Russia 4 Joint Vietnam- \\ Russian Tropical Research and Technological Centre, Nguyen Van Huyen, Nghia Do, Cau Giay, Hanoi, Vietnam
}

Corresponding author: Alexei V.Abramov (a.abramov@mail.ru)

Academic editor: Kristofer M. Helgen | Received 15 April 2012 | Accepted 2 July 2012 | Published 11 July 2012

Citation: Abramov AV, Bannikova AA, Rozhnov VV (2012) White-toothed shrews (Mammalia, Soricomorpha, Crocidura) of coastal islands of Vietnam. ZooKeys 207: 37-47. doi: 10.3897/zookeys.207.3237

\begin{abstract}
New findings of the white-toothed shrews (Crocidura spp.) from offshore islands of Vietnam are reported. The species identifications have been confirmed by the analysis of complete mitochondrial cytochrome $b$ gene $(1140 \mathrm{bp})$. Crocidura phuquocensis is the only species found in the Phu Quoc Island. Crocidura fuliginosa has been recorded from two islands of the Con Dao Archipelago (Con Son and Bai Canh). The occurrence of $C$. fuliginosa in Vietnam has been genetically confirmed for the first time. Crocidura attenuata has been collected from the Cat Ba Island for the first time, and this finding corresponds well with the proposal that the species' distribution is confined to the north and east of the Red River only.
\end{abstract}

\section{Keywords}

Crocidura fuliginosa, Crocidura attenuata, Crocidura phuquocensis, biogeography, Cat Ba, Con Dao, Phu Quoc, SE Asia

\section{Introduction}

Biodiversity of Southeast Asian islands has often been the focus of intensive studies by systematists, evolutionary biologists and biogeographers (Meijaard 2003; Esselstyn and Brown 2009; Esselstyn et al. 2009; Esselstyn and Oliveros 2010). Such studies of insular faunas of terrestrial mammals make it possible to examine geographic and 
temporal processes of diversification. The species distribution and richness of island faunas are determined by colonization and extinction events and are largely dependent on geographical characteristics of the islands, particularly their size and isolation.

Despite its small size, Vietnam has a very long coastline (near $3500 \mathrm{~km}$ ) and is surrounded by more than 3000 islands. The majority of Vietnamese coastal islands are situated within a shallow shelf. Two main stages of the geological history of this area can be recognized (Korotky et al. 1995). At the first stage, most parts of the modern South China Sea shelf were continental. During following transgressions the continent was submerged and many coastal islands developed. These islands were from time to time connected to the continent during repeated sea level fluctuations in the Pleistocene. Island communities off mainland Vietnam may reflect dispersal and vicariance events initiated by climate change.

Most mammal surveys of Vietnamese islands have been devoted to the study of rodents and large mammals (Van Peenen et al. 1970, Kuznetsov and Anh 1992, Kuznetsov 2000). Shrews remain poorly studied in these areas. A few biodiversity surveys were conducted by the Joint Vietnam-Russian Tropical Research and Technological Centre (VRTC) on coastal islands of Vietnam (Fig. 1) during 2003-2011. In this paper, we have summarized the results of the study of white-toothed shrews resulting from these surveys.

\section{Studied area}

Phu Quoc is the largest Vietnamese island (it covers ca. $562 \mathrm{~km}^{2}$ ) lying in the Gulf of Thailand, ca. $15 \mathrm{~km}$ south of the coast of mainland Cambodia. Primary lowland tropical forests still cover the northeastern part of the island. The first mammalogical survey of Phu Quoc was carried out of the VRTC (Abramov et al. 2007a) in the period of 25 November - 20 December, 2003. In total, 105 trap-nights were conducted using pitfall traps (plastic buckets $40 \times 30 \mathrm{~cm}$ ) located in a few different biotopes.

The Con Dao Archipelago is situated in the monsoon belt of the South China Sea at about $90 \mathrm{~km}$ off mainland Vietnam. Con Son, formerly known as Pulo Condor, consists of the largest (ca. $52 \mathrm{~km}^{2}$ ) island of archipelago, surrounded by 14 smaller islets. The topography of Con Son Island is mountainous, and is dominated by the granite ridge running from south-west to north-east and is covered by primary tropical forest. A biodiversity survey of Con Son was conducted by the VRTC from 26 May to 12 June, 2010. Small mammal trapping was conducted using plastic buckets $(25 \times 20$ $\mathrm{cm})$ and glasses $(13 \times 9 \mathrm{~cm})$ as pitfall traps. Trapping took place for a total of 1237 trapnights, distributed unequally between 13 survey sites.

Cat $\mathrm{Ba}$ is the largest of hundreds of islands that comprise the Cat $\mathrm{Ba}$ Archipelago and is located at the southeastern edge of Ha Long Bay in northern Vietnam. Cat Ba Island lies approximately $30 \mathrm{~km}$ east of Hai Phong city in northern Vietnam and has a surface area of $285 \mathrm{~km}^{2}$. The landscape of Cat $\mathrm{Ba}$ is dominated by limestone karst with alternating narrow valleys running along the northeast-southwest line. The main natural vegetation type on Cat Ba consists of moist tropical forest on limestone karst, 


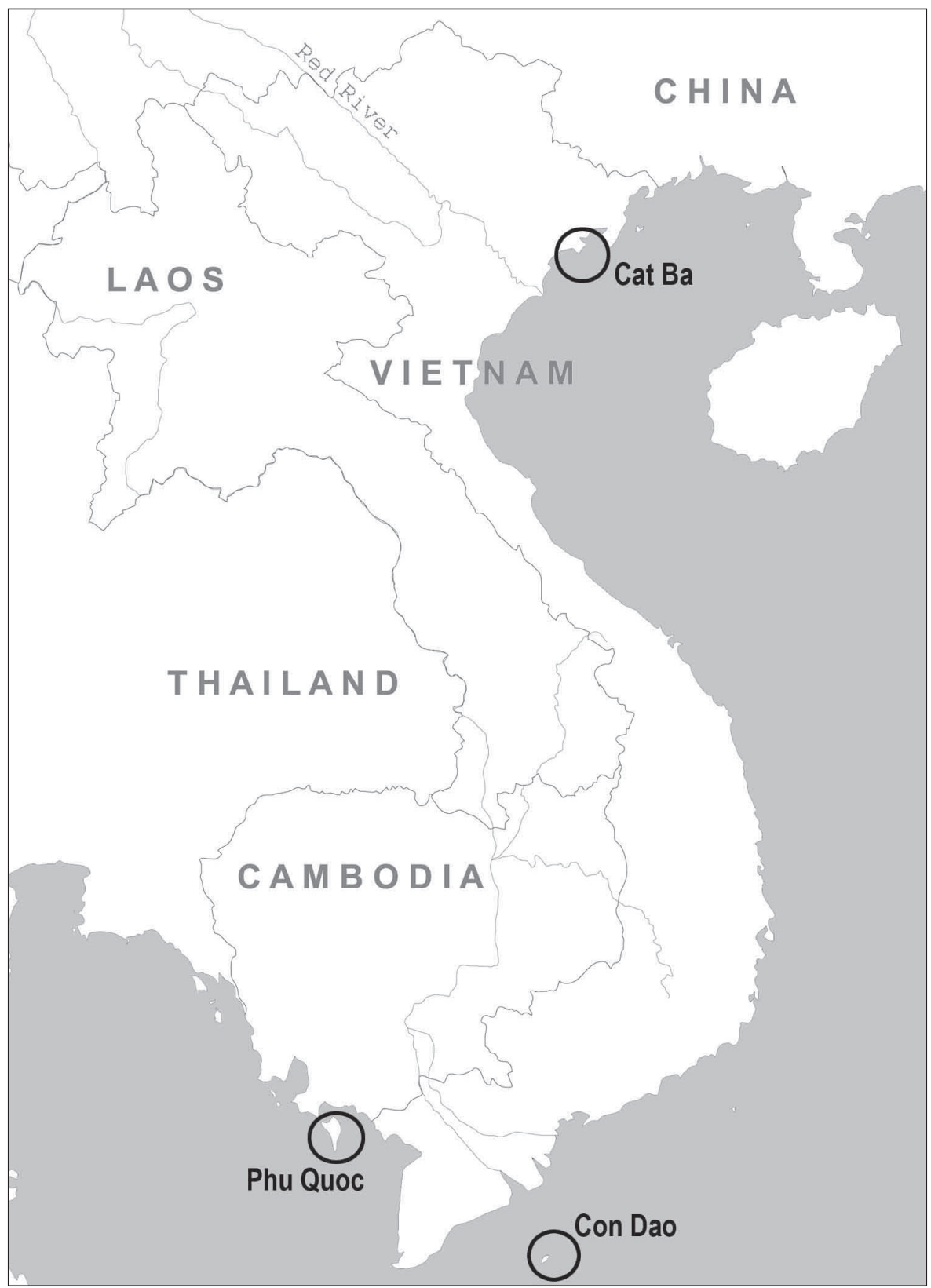

Figure I. Map of Vietnam. Location of islands studied is shown.

however, in large areas it is now replaced by limestone scrub or bare rocks. Fieldworks were carried out by the VRTC in the central part of Cat Ba Island from 10 to 25 October, 2011. In total, 650 trap-nights were conducted using pitfall traps (plastic glasses of $13 \times 9 \mathrm{~cm}$ ) located in five different biotopes. 


\section{Material and methods}

A total of thirteen Crocidura specimens were collected during the three aforementioned island surveys. Specimens were fixed in $70 \%$ ethanol. Tissue samples were preserved in $96 \%$ ethanol. Skulls were extracted and cleaned from many specimens. Standard external body measurements (head and body length, tail length, hind foot length) were taken in the field. Weight was measured in grams. Voucher specimens are kept in the Zoological Institute of the Russian Academy of Sciences (Saint-Petersburg, Russia).

Genomic DNA was isolated from ethanol-fixed kidney or muscles by proteinase K digestion, phenol-chloroform deproteinization and isopropanol precipitation (Sambrook et al. 1989).

The complete mitochondrial cytochrome $b$ gene (cytb, $1140 \mathrm{bp}$ ) was amplified by PCR with the primer combination and conditions for cytb amplification as in Bannikova et al. (2011). Primers L14728_Cr (5`-GACATGAAAAATCATCGTTGTTCTTCAAC-3`) and H1310_Cr (5`-GAATATCAGCTTTGGGTGYTGATGGTGG-3') were used for amplification of the whole cytb gene (1140 bp), and primers Cro_481b (5'-ACGGAAAAGCCTCCTCAGATTCATTCTAC-3') and L363A (5'-CGCAGTTATAGCCACCGCCTTTATAGG-3') were used for sequencing and amplification of short parts of the gene if necessary. Sequencing with each primer was performed by the ABI 3100-Avant autosequencing system using ABI $\mathrm{PRISM}^{\circ} \mathrm{BigDye}$ TM Terminator v. 3.1. Cytb gene sequences were aligned by eye using BioEdit v.7.0.5.3 (Hall 1999). The final alignment of the mitochondrial gene included $1140 \mathrm{bp}$. Diversity patterns of cytb sequences were assessed using maximum parsimony (MP) and neighbour joining (NJ) methods with the help of PAUP* version $4.0 \mathrm{~b} 10$ (Swofford 1998) based on pairwise $p$-distance matrix. To assess clade support, 1000 bootstrap pseudoreplicates were analyzed.

GenBank accession numbers for the original sequences used in the study are JX181934-JX181941.

We also included $c y t b$ sequence data from several earlier studies (Ruedi et al. 1998; Bannikova et al. 2006, 2011; Dubey et al. 2008; Esselstyn et al. 2009; Lavrenchenko et al. 2009) to place the shrews from Vietnam into a regional phylogeographic and phylogenetic context.

\section{Results}

\section{Crocidura fuliginosa (Blyth, 1855)}

http://species-id.net/wiki/Crocidura_fuliginosa

Remarks. We have found this species on Con Son Island only. A single specimen was collected near Nui Nha Ban on the north slope of Nui Chua Mt. in the central part of island. The pitfall traps $\left(08^{\circ} 42^{\prime} 49^{\prime \prime} \mathrm{N}, 106^{\circ} 37^{\prime} 13^{\prime \prime} \mathrm{E}\right)$ were set in moist primary forest at an elevation of $250 \mathrm{~m}$ asl. Despite considerable trapping efforts (more than 1200 trap- 
nights) we collected only one specimen. This species was firstly reported from Con Son by Van Peenen et al. (1970). A single adult male (USNM 357348, Smithsonian Institution) was caught in a small Sherman trap at the side of a trail leading to Nui Nha Ban, at the elevation of $80 \mathrm{~m}$ asl. Another specimen (ZMMU S-144368, Zoological Museum of Moscow University) was collected in 1987 in the forest of Bai Canh Islet located just $1 \mathrm{~km}$ eastward of the Con Son Island.

This is a large, long-tailed Crocidura; tail 79\% of head and body length, on average. Means and extremes of measurements (in $\mathrm{mm}$ ) from 3 adults are: head and body length, 87.0 (83-90); tail length, 68.3 (67-71); hind foot length, 15.7 (15-17); weight $(\mathrm{n}=1), 16.7 \mathrm{~g}$.

The mtDNA analysis suggests that specimen from the Con Son Island belongs to C. fuliginosa (Fig. 2).

Many papers listed $C$. fuliginosa as being widespread in mainland Vietnam (Heaney and Timm 1983; Huynh et al. 1994; Kuznetsov 2006; Can et al. 2008; Jenkins et al. 2009). A recent comparative study of mtDNA (Bannikova et al. 2011) did not confirm its occurrence in Vietnam. Specimens from northern Vietnam (Ha Giang Province) are very different from the shrews taken from the Cameron Highlands (Peninsular Malaysia) assigned to this species. Moreover, the northern Vietnamese specimens are close to the shrews from Yunnan, southern China. A major distinction between Yunnan specimens and $C$. fuliginosa from Peninsular Malaysia was also found by Dubey et al. (2008) in the analysis of nuclear genes. Bannikova et al. (2011) proposed to re-establish the name $C$. dracula for the large white-toothed shrews from northern Vietnam and southern China. This taxon was described by Thomas (1912) from southern Yunnan. According to Allen (1938) and Ellerman and Morrison-Scott (1951), this species is distributed across southern China and adjacent Indochina. Jenkins (1976) considered dracula a subspecies of $C$. fuliginosa, and was followed in this opinion by various authors (Heaney and Timm 1983; Jiang and Hoffmann 2001; Hutterer 2005). Based on the data from mitochondrial DNA, the name fuliginosa was provisionally restricted to the shrews from the southern part of Southeast Asia, including Malaysia and southern Myanmar (Bannikova et al. 2011). A comparison of cytb sequences suggests that specimen from the Con Son Island belongs to this haplogroup (Fig. 2). This is a first genetically confirmed record of $C$. fuliginosa from Vietnam.

The occurrence of $C$. fuliginosa sensu stricto in mainland Vietnam is still questionable (see also Heaney and Timm 1983). Jenkins et al. (2009) have mentioned museum specimens of $C$. fuliginosa (= dracula sensu Bannikova et al. 2011) from Lao Cai in northern Vietnam and Yunnan in southern China only. Two other records mentioned by Jenkins et al. (2009) were based on survey reports, not on museum voucher specimens. One of them (Trai et al. 1999), reporting C. fuliginosa from Ngoc Linh Mt. in Kon Tum Province, central Vietnam, was based on a visual observation only. Another location mentioned (see Jenkins et al. 2009) is Nui Bi Doup, Lam Dong Province, southern Vietnam. In 2004 and 2006, during mammal surveys in Ngoc Linh Mt. conducted by the VRTC, we collected 116 shrews of three Crocidura species (Abramov et al. 2007b; Rozhnov and Abramov 2009). Two of these species, C. sokolovi and $C$. 
zaitsevi, were new to science (Jenkins et al. 2007); the third one was C. tanakae (see Bannikova et al. 2011). Several biodiversity surveys conducted by the VRTC in Nui Bi Doup area in 2002-2009 (Abramov et al. 2010) yielded more than 100 shrews of three Crocidura species, including C. tanakae, C. indochinensis and C. zaitsevi (see Bannikova et al. 2011). However, we documented no specimens of $C$. fuliginosa, neither in the Ngoc Linh nor in the Bi Doup areas.

\section{Crocidura phuquocensis Abramov, Jenkins, Rozhnov et Kalinin, 2008} http://species-id.net/wiki/Crocidura_phuquocensis

Remarks. Five adult white-toothed shrews were collected in the northern part of Phu Quoc Island (10²2'53"N, 10400'19"E), $5 \mathrm{~km}$ west of Bai Thom Village, near the road Duong Dong-Bai Thom, close to the northern slope of Mount Chua area, at the elevation of about $30 \mathrm{~m}$ asl. Pitfall traps were set up in the dipterocarp forest, near tumbled down trees, at the bottom of a mountain. On the basis on these specimens, C. phuquocensis was described by Abramov et al. (2008).

This is a medium-sized Crocidura, with a moderately long tail; tail $75 \%$ of head and body length, on average. Means and extremes of measurements (in $\mathrm{mm}$ ) from 5 adults are: head and body length, 76.2 (68-72); tail length, 52.4 (49-59); hind foot length, 12.1 (12-12.5).

The validity of this species was recently confirmed by comparison of $c y t b$ and COI sequences with available reference data (Bannikova et al. 2011). On the $c y t b$ tree, the C. phuquocensis haplogroup is the nearest neighbour to the C. fuliginosa - C. dracula group, although with low bootstrap support (Fig. 2).

Phu Quoc lies very close to mainland Cambodia. The Phu Quoc rainforests belong to the Cardamom Mountain rain forests ecoregion (MacKinnon 1997). Overall, the small mammal fauna of Phu Quoc is similar to that of the Cardamom Mountains (Swan and Kry 2000; Abramov et al. 2007a). Presumably, C. phuquocensis (currently known from Phu Quoc only) may also be found in the adjacent mainland.

\section{Crocidura attenuata Milne-Edwards, 1872}

http://species-id.net/wiki/Crocidura_attenuata

Remakrs. We collected seven specimens of this species from Cat Ba Island. The trapping line $\left(20^{\circ} 48^{\prime} \mathrm{N}, 106^{\circ} 59^{\prime} \mathrm{E}\right)$ was located along the west part of tourist trail from the Cat Ba National Park Headquarters to Viet Hai Village. All specimens were caught in pitfall traps set in mixed forest near limestone bare rocks. It is the first record of Crocidura from Cat Ba Island.

This is a medium-sized Crocidura, with a moderately long tail; tail $79.8 \%$ of head and body length, in average. Means and extremes of measurements (in $\mathrm{mm}$ ) from 5 adults are: head and body length, 74.6 (71-79); tail length, 59.2 (57-62); hind foot length, 13.2 (12-14); weight $(n=4), 9.8(7.3-11.5) \mathrm{g}$. 


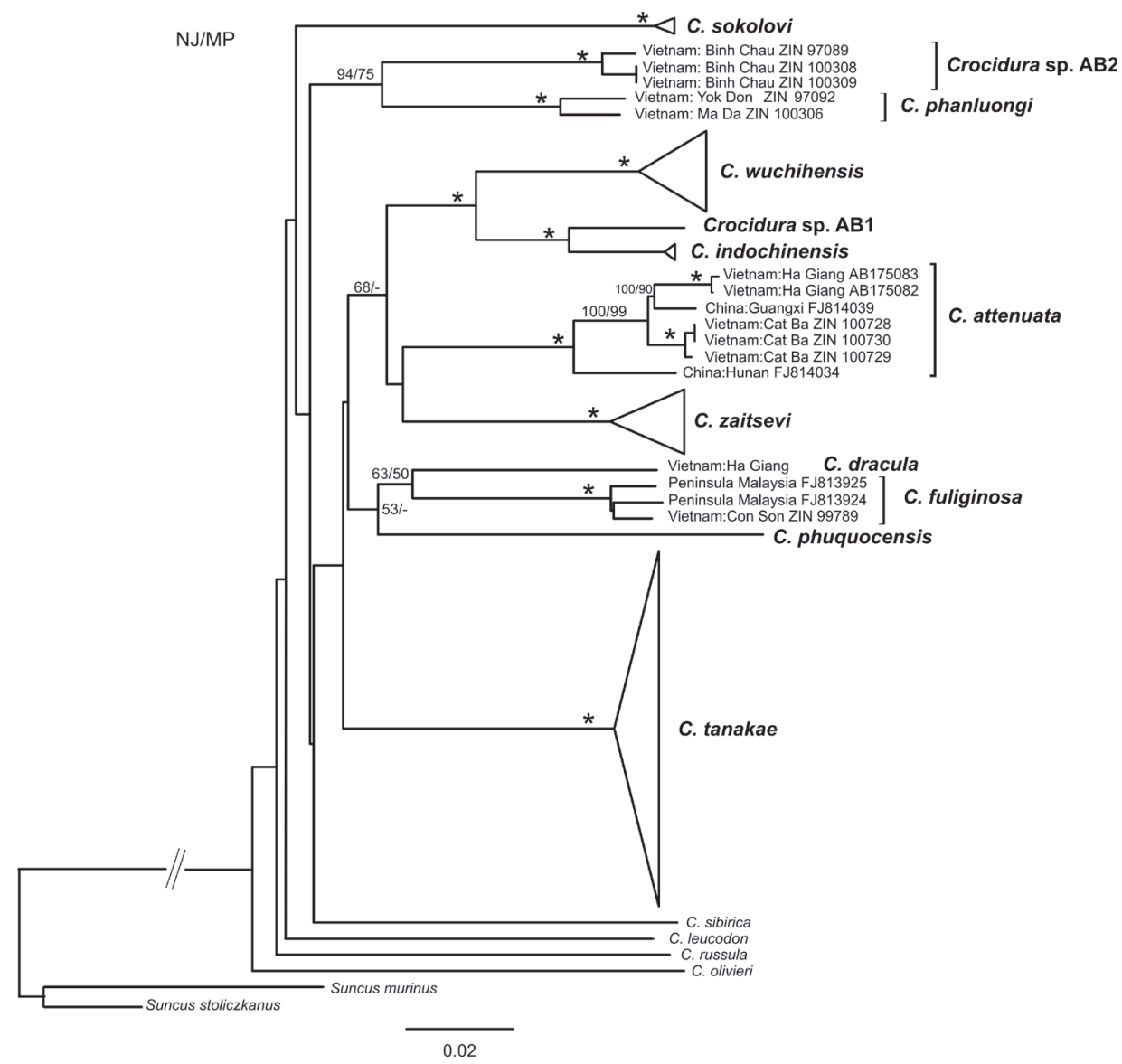

Figure 2. The NJ tree for the $c y t b$ gene. The bootstrap values ( ${ }^{3} 50 \%$ ) obtained from 1000 replications in NJ/ MP analyses are presented above the branches. «* denotes bootstrap support of $100 \%$ in both NJ and MP analyses; «-» indicates support values of less than $50 \%$. Suncus murinus and S. stoliczkanus are used as outgroup.

Analysis of mitochondrial DNA confirmed that the specimens from Cat Ba belong to C. attenuata proper. All the analyzed specimens from Cat Ba (see Fig. 2) formed a single cluster closely related to the group of specimens from northern Vietnam $(\mathrm{Ha}$ Giang Province) and southeastern China (Guangxi Province). The genetic distance ( $p$-distance) between specimens from $\mathrm{Cat} \mathrm{Ba} / \mathrm{Ha}$ Giang as well as $\mathrm{Cat} \mathrm{Ba} / \mathrm{Guangxi}$ is about $2.1 \%$. The specimen of $C$. attenuata from the more north-eastern region of China (Hunan Province) appears basal among all samples of $C$. attenuata from China and Vietnam. Thus, the genetic distance between two specimens from China (Hunan/ Guangxi) is $4.3 \%$, which is nearly the same as the distance between $C$. indochinensis/C. sp. AB1. Thus, genetic differentiation of $C$. attenuata is notable and reveals a phylogeographic structure with four haplogroups.

Most authors (Heaney and Timm 1983; Huynh et al. 1994; Hutterer 2005; Kuznetsov 2006; Can et al. 2008; Jenkins et al. 2009) have suggested a wide geo- 
graphic distribution for $C$. attenuata in Vietnam. However, the recent study of mitochondrial DNA (Bannikova et al. 2011) restricted the distribution of $C$. attenuata proper to the northernmost part of Vietnam. Elsewhere in mainland Vietnam, it is replaced by $C$. tanakae. The latter species was previously considered an endemic of Taiwan (Motokawa et al. 1997, 2001; Hutterer 2005). However, based on mtDNA data analyses, the name $C$. tanakae has been applied to all white-toothed shrews that are genetically similar to the Taiwanese haplogroup. This haplogroup is widely distributed across mainland Asia, including in southern China, Vietnam and Laos (Esselstyn et al. 2009, 2010; Bannikova et al. 2011).

Documentation of $C$. attenuata on Cat Ba Island well corresponds to the proposed species' distribution confined to the north and east of the Red River (see Bannikova et al. 2011).

\section{Conclusion}

Current distributions and phylogenetic relationships of Crocidura species from Vietnamese offshore islands support the hypothesis that shrews may have colonized the islands relatively recently. It is known that the non-volant mammal fauna of these islands was formed during the period when most parts of the modern South China Sea shelf were continental (see also Kuznetsov and Anh 1992; Kuznetsov 2000).

Cat $\mathrm{Ba}$ Island is a part of the extended region of the Viet Bac Karst zone, stretching from southeastern China to northeastern Vietnam (Tuyet 1998), and its mammal fauna is similar to that of the adjacent mainland (Abramov and Kruskop 2012). The low level of divergence between mainland populations of $C$. attenuata and that from Cat $\mathrm{Ba}$ seem to correspond to recent faunal exchanges in northeastern Vietnam, including Cat Ba Island. Crocidura phuquocensis, the only endemic species of white-toothed shrew from coastal islands of Vietnam, is very likely to be found in the Cardamom Mountains of the adjacent mainland, if targeted small mammals surveys are undertaken there.

Sister relationships between the Con Son and Malaysian populations of C. fuliginosa suggest that its distribution might have been more extensive in the past. However, data on this species' occurrence in Southeast Asia are very scarce and doubtful. Morphological characters and genetic variation of the populations from Thailand, Laos, Cambodia and Myanmar referred to as C. fuliginosa (Corbet and Hill 1992; Ruedi 1995; Francis 2008) need to be examined in detail.

\section{Acknowledgements}

We thank the administration of the Joint Vietnam-Russian Tropical Research and Technological Centre, and notably Dr. A.N. Kuznetsov for talented organization of field work. We are grateful to the administrations of the Phu Quoc, Con Dao, and 
Cat Ba National Parks for providing us with an opportunity to carry out field surveys. AA thanks Dr. A.A. Kalinin and A.V. Shchinov who helped out with field collecting. We are obliged to Dr. D.V. Logunov (Manchester, UK) for linguistic help. We are very grateful to Dr. Manuel Ruedi and two anonymous reviewers for their helpful and constructive comments on the early version of the manuscript. This work was supported in part by the Ministry of Education and Science of Russian Federation and by the Russian Foundation for Basic Research (projects 11-04-00020, 12-04-93005).

\section{References}

Abramov AV, Kruskop SV (2012) The mammal fauna of Cat Ba Island, northern Vietnam. Russian Journal of Theriology 11: 57-72.

Abramov AV, Kalinin AA, Morozov PN (2007a) Mammal survey on Phu Quoc Island, southern Vietnam. Mammalia 71: 40-46. doi: 10.1515/MAMM.2007.001

Abramov AV, Rozhnov VV, Morozov PN (2007b) Notes on mammals of the Ngoc Linh Nature Reserve (Vietnam, Kon Tum Province). Russian Journal of Theriology 5: 85-92.

Abramov AV, Jenkins PD, Rozhnov VV, Kalinin AA (2008) Description of a new species of Crocidura (Soricomorpha: Soricidae) from the island of Phu Quoc, Vietnam. Mammalia 72: 269-272. doi: 10.1515/MAMM.2008.033

Abramov AV, Kruskop SV, Shchinov AV (2010) Small mammals of the Dalat Plateau, southern Vietnam. Russian Journal of Theriology 8: 61-73.

Allen GM (1938) The Mammals of China and Mongolia. American Museum of Natural History, New York, 620 pp. doi: 10.5962/bhl.title.12195

Bannikova AA, Abramov AV, Borisenko AV, Lebedev VS, Rozhnov VV (2011) Mitochondrial diversity of the white-toothed shrews (Mammalia, Eulipotyphla, Crocidura) in Vietnam. Zootaxa 2812: 1-20.

Bannikova AA, Lebedev VS, Kramerov DA, Zaitsev MV (2006) Phylogeny and systematics of Crocidura suaveolens species group: corroboration and controversy between nuclear and mitochondrial DNA markers. Mammalia 70: 106-119. doi: 10.1515/MAMM.2006.011

Can DN, Endo H, Son NT, Oshida T, Canh LX, Phuong DH, Lunde DP, Kawada S-I, Hayashida A, Sasaki M (2008) Checklist of Wild Mammal Species of Vietnam. Institute of Ecology and Biological Resources, Hanoi, 400 pp.

Corbet GB, Hill JE (1992) The Mammals of the Indomalayan Region. Oxford University Press, Oxford, 488 pp.

Dubey S, Salamin N, Ruedi M, Barriere P, Colyn M, Vogel P (2008) Biogeographic origin and radiation of the Old World crocidurine shrews (Mammalia: Soricidae) inferred from mitochondrial and nuclear genes. Molecular Phylogenetics and Evolution 48: 953-963.

Ellerman JR, Morrison-Scott TCS (1951) Checklist of Palaearctic and Indian Mammals, 1758 to 1946. Trustees of the British Museum (Natural History), London, $810 \mathrm{pp}$.

Esselstyn JA, Brown RM (2009) The role of repeated sea-level fluctuations in the generation of shrew (Soricidae: Crocidura) diversity in the Philippine Archipelago. Molecular Phylogenetics and Evolution 53: 171-181. doi: 10.1111/j.1558-5646.2009.00743.x 
Esselstyn JA, Oliveros CH (2010) Colonization of the Philippines from Taiwan: a multi-locus test of the biogeographic and phylogenetic relationships of isolated populations of shrews. Journal of Biogeography 37: 1504-1514.

Esselstyn JA, Timm RM, Brown RM (2009) Do geological or climatic processes drive speciation in dynamic archipelagos? The tempo and mode of diversification in Southeast Asian shrews. Evolution 63: 2595-2610.

Francis CM (2008) A Field Guide to the Mammals of South-East Asia. New Holland, London, 392 pp.

Hall TA (1999) BioEdit: a user-friendly biological sequence alignment editor and analysis program for Windows 95/98/NT. Nucleic Acids Symposium Series 41: 95-98.

Heaney LR, Timm RM (1983) Systematics and distribution of shrews of the genus Crocidura (Mammalia: Insectivora) in Vietnam. Proceedings of the Biological Society of Washington 96: $115-120$.

Huynh DH, Tien DV, Sung CV, Anh PT, Khien HM (1994) Checklist of Mammals in Vietnam. Publ. House "Science \& Technics", Hanoi, 168 pp.

Hutterer R. (2005) Order Soricomorpha. In: Wilson DE, Reeder DM (Eds) Mammal Species of the World. A Taxonomic and Geographic Reference. Third edition. Johns Hopkins University Press, Baltimore, 220-311.

Jenkins PD (1976) Variation in Eurasian shrews of the genus Crocidura (Insectivora: Soricidae). Bulletin of the British Museum (Natural History), Zoology 30: 271-309.

Jenkins PD, Abramov AV, Rozhnov VV, Makarova OV (2007) Description of two new species of white-toothed shrews belonging to the genus Crocidura (Soricomorpha: Soricidae) from the Ngoc Linh Mountain, Vietnam. Zootaxa 1589: 57-68.

Jenkins PD, Lunde DP, Moncrieff CB (2009) Chapter 10. Descriptions of new species of Crocidura (Soricomorpha: Soricidae) from mainland Southeast Asia, with synopses of previously described species and remarks on biogeography. In: Voss RS, Carleton MC (Eds) Systematic mammalogy: contributions in honour of Guy G. Musser. Bulletin of the American Museum of Natural History 331: 356-405.

Jiang X, Hoffmann RS (2001) A revision of the white-toothed shrews (Crocidura) of southern China. Journal of Mammalogy 82: 1059-1079. doi: 10.1644/1545-1542(2001)082<1059:AR OTWT>2.0.CO;2

Korotky AM, Razjigaeva NG, Ganzey LA, Volkov VG, Grebennikova TA, Bazarova VB, Kovalukh NN (1995). Late Pleistocene-Holocene coastal development of islands off Vietnam. Journal of Southeast Asian Earth Sciences 11: 301-308. doi: 10.1016/0743-9547(94) E0016-7

Kuznetsov GV (2000) Mammals of coastal islands of Vietnam: zoogeographical and ecological aspects. Bonner Zoologische Monographien 4: 357-366.

Kuznetsov GV (2006) Mammals of Vietnam. KMK Scientific Press, Moscow, 420 pp. [in Russian] Kuznetsov GV, Anh PT (1992) Mammals of coastal islands of Vietnam (biogeographical and ecological aspects). In: Sokolov VE (Ed) Zoological Studies in Vietnam. Nauka, Moscow, 182-197. [in Russian] 
Lavrenchenko LA, Bannikova AA, Lebedev VS (2009) Shrews (Crocidura spp.) endemic to Ethiopia: recent adaptive radiation of an ancient lineage. Doklady Biological Sciences 424: 57-60. doi: 10.1134/S0012496609010177

MacKinnon J (1997) Protected Areas Systems Review of the Indo-Malayan Realm. The Asian Bureau for Conservation, Canterbury, 198 pp.

Meijaard E (2003) Mammals of south-east Asian islands and their Late Pleistocene environments. Journal of Biogeography 30: 1245-1257. doi: 10.1046/j.1365-2699.2003.00890.x

Motokawa M, Harada M, Lin LK, Koyasu K, Hattori S (1997) Karyological study of the gray shrew Crocidura attenuata (Mammalia: Insectivora) from Taiwan. Zoological Studies 36: 70-73.

Motokawa M, Harada M, Wu Y, Lin LK, Suzuki H (2001) Chromosomal polymorphism in the gray shrew Crocidura attenuata (Mammalia: Insectivora). Zoological Science 18: 1153-1160. doi: $10.2108 /$ zsj.18.1153

Rozhnov VV, Abramov AV (2009) Insectivorous mammals of Ngoc Linh Mt., Vietnam. In: Rozhnov VV et al. (Eds) Fauna of Mountain Territories. KMK Scientific Press, Moscow, 455-459. [in Russian]

Ruedi M (1995) Taxonomic revision of shrews of the genus Crocidura from the Sunda Shelf and Sulawesi with description of two new species (Mammalia: Soricidae). Zoological Journal of the Linnean Society 115: 211-265. doi: 10.1111/j.1096-3642.1995.tb02461.x

Ruedi M, Auberson M, Savolainen V (1998) Biogeography of Sulawesian shrews: testing for their origin with a parametric bootstrap on molecular data. Molecular Phylogenetics and Evolution 9: 567-571. doi: 10.1006/mpev.1998.0487

Sambrook J, Fritsch EF, Maniatis T (1989) Molecular Cloning: a Laboratory Manual. Cold Spring Harbor Lab. Press, Cold Spring Harbor, New York, 398 pp.

Swofford DL (1998) PAUP*. Phylogenetic Analysis Using Parsimony (*and Other Methods). Version 4. Sinauer Associates, Sunderland, MA.

Swan SR, Kry M (2000) Small mammals. In: Daltry JC, Momberg F (Eds) Cardamom Mountains Survey 2000. Fauna \& Flora International, Cambridge, UK, 69-78.

Thomas O (1912) New species of Crocidura and Petaurista from Yunnan. Annals and Magazine of Natural History 8: 686-688. doi: 10.1080/00222931208693186

Trai LT, Richardson WJ, Tuyen BD, Cham LV, Dung NH, Hoach HV, Monastyrskii AL, Eames JC (1999) An Investment Plan for Ngoc Linh Nature Reserve, Kon Tum Province, Vietnam: A Contribution to the Management Plan. BirdLife International Vietnam Programme, Hanoi, 106 pp.

Tuyet D (1998) Overview on karst of Vietnam. In: Yuan D, Liu Z (Eds) Global Karst Correlation. Science Press, Beijing, 179-191.

Van Peenen PFD, Cunningham ML, Duncan JF (1970) A collection of mammals from Con Son Island, Vietnam. Journal of Mammalogy 51: 419-424. doi: 10.2307/1378509 